\title{
Healthy Skin Naturally
}

Henry B. Balfanz, M.B.A., Northern Michigan University, USA Gary J. Brunswick, Ph.D., Northern Michigan University, USA Margaret Sklar, Ph.D., Northern Michigan University, USA

\section{CASE DESCRIPTION}

This case focuses on a start-up business trying to find a profitable niche' in the skin care market in southern California. Entering a highly competitive industry, Healthy Skin Naturally is trying to determine the proper sales, distribution and promotional strategies to attain their sales goal of $\$ 500,000$ in the next three years. Over the time that the products have been produced, the owners report that the "feedback from users tell us that they are all very effective"; it's the opinion of the owners of Healthy Skin Naturally that price is a secondary factor to buyers as long as the products are effective in helping solve skin problems. Covering a geographic area from Santa Barbara to San Diego, the owners are targeting white collar professional women aged 35 to 70 , as well as teenage acne sufferers and men of all ages. This case would be appropriate for sophomore-junior level students. The case can be taught in 2 to 3 hours and expected to require 3-5 hours of outside preparation by students. Research into skincare issues might be helpful before attempting this case.

\section{CASE SYNOPSIS}

This case features Mina Law Glassman, a licensed marriage and family therapist, who has been creating her own skin care formulations, with the help of a chemist, for many years. In addition to her family therapy practice, Ms. Glassman is also a licensed Skincare Therapist in the state of California. As a Skincare Therapist, she discovered she had a talent for combining ingredients to create effective solutions to skin care problems. Now, at the urging of her husband, Jim Glassman, they are trying to expand the business beyond the small customer base they have now. Ms. Glassman currently has personal skin care clients and one plastic surgeon purchasing the products, cumulatively spending well under \$50,000 annually. It has been a part time business for Ms. Glassman; the couple's hope is that they can grow Healthy Skin Naturally into a highly profitable fulltime business, attaining a sales goal of $\$ 500,000$ in the third year hence. Ms. Glassman serves as President and Mr. Glassman as CEO of Healthy Skin Naturally.

Keywords: Marketing Case Study; Start-Up Business Case Study

\section{INTRODUCTION}

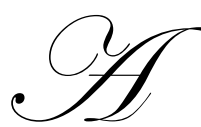

s Mina Law Glassman was breezing down California's famed highway one in her late model red Thunderbird convertible, she turned up the radio. What an appropriate song, she thought. The sounds of Jerry Garcia and the Grateful Dead from an L. A. oldies station were coming in loud and clear, and she couldn't help but reflect on her past when she heard the lyric, "what a long strange trip it's been....", from the Dead's classic 'Truckin'. Mina thought about how the product line she and her husband started working on years ago - Healthy Skin Naturally - changed and evolved in unexpected ways, and what challenges and opportunities will the next 10 years bring ?

What started as yet another attempt, years ago, to find a solution to her lifelong acne condition and eventually turned into a part time occupation in helping others find solutions to their skin problems, Ms. Glassman and her husband were now on the brink of launching a fulltime enterprise helping others, working together, with hopes of succeeding. 
After years of suffering, Ms. Glassman came upon a solution to her lifelong acne problem through the help of Mary Smith, a childhood friend and then a Chiropractic student. Prior to finding this solution, no cure she tried seemed to work. Antibiotics, the usual over the counter drugs, traditional prescriptions from physicians---nothing helped and some even seemed to exacerbate the long term condition. As she struggled through the years of trying to find the magical solution, she made a vow to herself that, if indeed she did come up with a solution, she would share it with as many acne sufferers as she possibly could.

When Ms. Glassman received the solution from Mary Smith, she was at a point emotionally where she was willing to try any cure that might come her way. Little did she know that the package of herbs sent to her would almost immediately end her acne problem and introduce her to someone who would become a lifelong mentor. A herbologist had visited her friend's classroom, and talked about the healing powers of the herbs that he had brought with him. He handed out free samples to the class. Ms. Glassman's friend sent the herbs to her, and she immediately tried the solution.

The positive results, obviously, made her want to learn more. She learned that the herbologist was a distributor of natural herbal products, and that he had obtained the herbs from a chemist in Orange County, California. Needless to say, after years of struggling to find a cure, Ms. Glassman was curious about the man who had created the solution to her lifelong acne problem.

Ms. Glassman met the Orange County chemist, Dr. Clyde Johnson, and decided to attend his Institute for Natural Herbal Pharmacology. At the institute, she learned how to compound the various ingredients of herbs, cod liver oil, and other ingredients. After completing the institute, Ms. Glassman began the process to complete the education and licensing necessary to become a Skincare Therapist in the state of California. She studied and learned the capabilities of the ingredients she had available for skin problems, ranging from dry to blemished to sundamaged skin. She learned the limitations of each, and reasoned that perhaps by combining ingredients that some of the more difficult problems might be minimized with new formulations of established products.

Success didn't immediately come to her door. One of the obstacles of creating formulations of the ingredients is the fact that the combinations "not only looked bad, but smelled pretty bad, too, " remembers Ms. Glassman. The early clients that Ms. Glassman dealt with taught her the lesson that, despite the promises of the product, if it is not appealing or at least neutral in appearance, odor, and feel, it won't even be sampled. In search of finding a solution, she met a chemist who had a private label lab. She instantly connected with him and now has been associated with him for over twenty years. The chemist had long developed formulations for well-known brands in addition to the private label work he had done. He had the magic touch in making the product not only effective, but appealing to all the senses as well.

The market for her products, up to this point, has been a relatively small handful of people; Ms. Glassman didn't consider that her talents in formulating with the help of the chemist could be used to create a fulltime business. It's only been through the urgings and assistance of her husband that she has agreed to take the product out of the realm of a part time hobby into a fulltime business.

"I hope this is just more than a dream," Ms. Glassman said to herself, as she pulled her red Thunderbird convertible off the highway and into the parking lot of a spa whose owner had expressed interest in carrying the Healthy Skin Naturally line. She was meeting Jim, her husband, as they were planning to make a joint presentation to the prospect. As Mina was gathering her materials for the presentation, Jim pulled up next to her, jumped out of his car, and said to Mina ,"Are you ready for this ?". Mina knowingly looked at Jim, nodded her head, and responded," Let's go".

\section{A GOOD OPPORTUNITY}

Southern California, according to Ms. Glassman, is a terrific test market for the development of her products. "People here are open to trying new things and new solutions, from new wines to new cars to new skin treatments," she says. 
The Glassmans define the target market as women 35-70 who are middle-to-upper income white professionals. A secondary market that they've identified is women with acne problems who are in their late teens to early twenties. Men, also a secondary market, comprise less than ten percent of their business. Initially, the Glassmans are trying to get the product into spas, doctors, plastic surgeons and dermatologists in the geographic area from Santa Barbara to San Diego, California. It is their belief that by doing so they can attain their sales goal of $\$ 500,000$ a year by the end of the third year after this one.

Another attraction of doing business in southern California is the fact that the sun shines brightly the year around. There are literally millions of people who moved there for that reason alone. The warnings about the sun's damaging rays, however, are not often heeded by the sun worshippers, creating short and long term problems for those who insist upon spending hours on the beach and/or in the sun every day. Fair skinned with auburn hair herself, Ms. Glassman has a great amount of respect for the sun and has seen firsthand as a Skincare Therapist how harmful ultraviolet rays can be. While working in a southern California spa, Ms. Glassman had developed quite a following of customers who visited the spa on a regular basis for her assistance with their skin issues, many related to sun and water exposure.

In short, Ms. Glassman knows and understands the skin care market as it exists today in southern California.

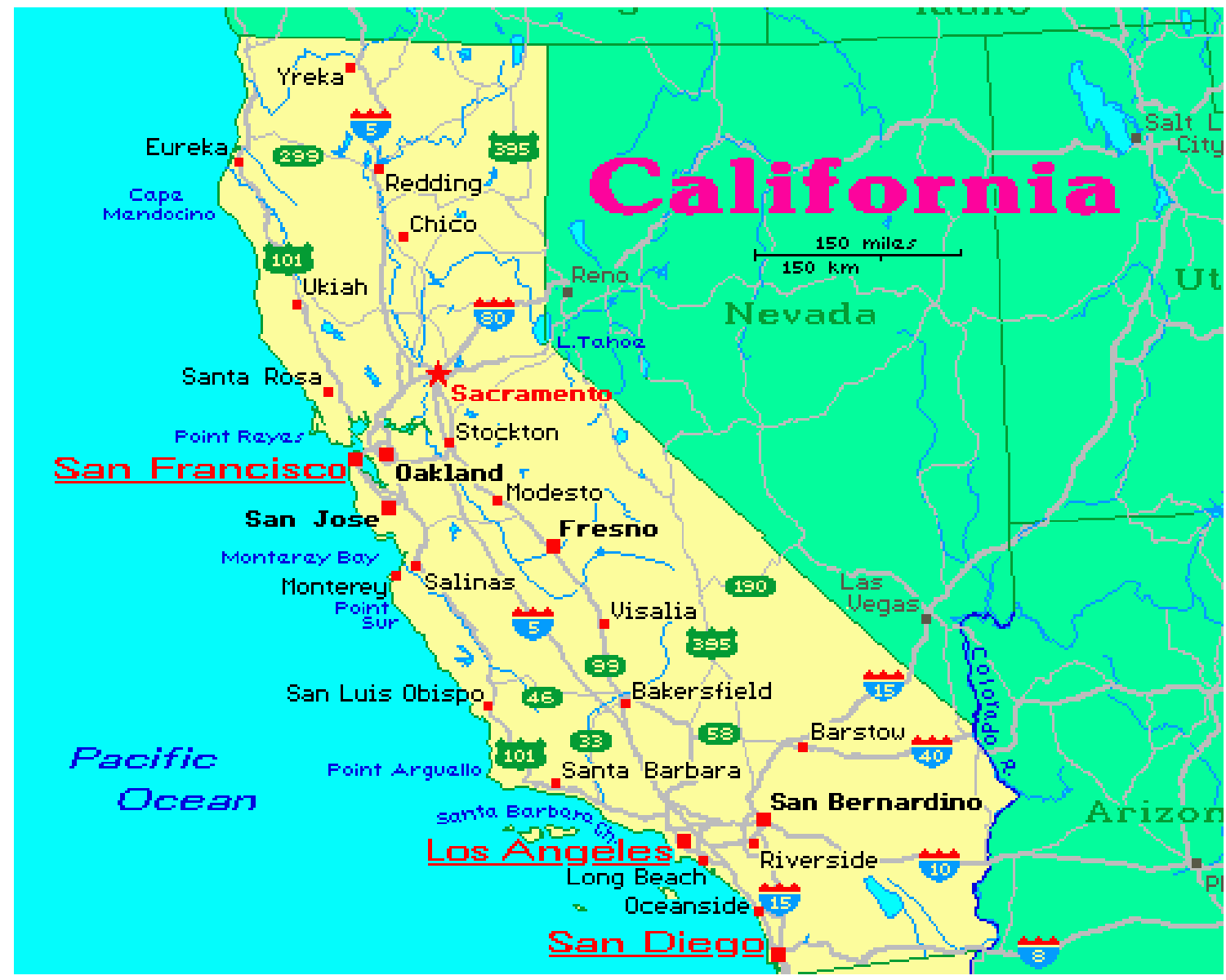




\section{CONTINUOUS PRODUCT IMPROVEMENT}

One of the practices that Ms. Glassman makes herself adhere to religiously is the habit of always looking for ways to improve her products. Because of her work with the chemist, she now has access to "white papers" on lab research on different ingredients and compounds. Some of these ingredients and compounds had patents that had recently expired and are now available for all private labels to use. By using the aforementioned research and formerly patented ingredients, she now has strong tools to formulate the proper percentages of ingredients in order to create and test different combinations to test on her patients.

In Ms. Glassman's own words, she and the chemist she works with would review an ingredient, and then say, "let's purchase it and try it."

Ms. Glassman is dedicated to creating better solutions to create happier customers. "I'm always upgrading," she says. "I can test clinically with plenty of my own clients. I keep track of the percentages used of the ingredients, and only use the ones proven to be most beneficial."

The problems of her clientele are pretty much average skin problems. " $30 \%$ of my clients have blemish issues. I don't deal with the more severe skin problems."

She's proud of the fact that she is now working with three generations of women in the same family. She jokingly refers to her early clients as "ones from what I call the 'stinky days', before I got the help of a chemist."

Through the process of trial and error, the line has grown into an array of 33 different lotions and treatments designed to help with most skin care problems commonly experienced by both men and women.

\begin{tabular}{|c|c|c|c|}
\hline Qty & Item Description & Size & Retail \\
\hline \multicolumn{4}{|c|}{ Cleansers } \\
\hline & Oak Cleanser & $8 \mathrm{oz}$ & $\$ 36.00$ \\
\hline & Skin Soothing Cleanser & $8 \mathrm{oz}$ & $\$ 36.00$ \\
\hline & Clear-Up Now! Cleanser & $8 \mathrm{oz}$ & $\$ 36.00$ \\
\hline & Luxe Citrus Gel Cleanser & $8 \mathrm{oz}$ & $\$ 34.00$ \\
\hline & Clear-Up Scrub & $8 \mathrm{oz}$ & $\$ 36.00$ \\
\hline & Cleansing (Almond) Scrub & $4 \mathrm{oz}$ & $\$ 32.00$ \\
\hline \multicolumn{4}{|c|}{ Moisturizers } \\
\hline & Moisture Balance & $2 \mathrm{oz}$ & $\$ 38.00$ \\
\hline & UltraLuxe Moisture Crème & $2 \mathrm{oz}$ & $\$ 48.00$ \\
\hline \multicolumn{4}{|l|}{ Masks } \\
\hline & Purifying Mask- Step 1 & $2 \mathrm{oz}$ & $\$ 26.00$ \\
\hline & Purifying Mask- Step 2 & $4 \mathrm{oz}$ & $\$ 34.00$ \\
\hline & Aloe A Gel Mask & $2 \mathrm{oz}$ & $\$ 34.00$ \\
\hline & Clear-Up Mask & $2 \mathrm{oz}$ & $\$ 34.00$ \\
\hline & Luxe Masking Treatment (with Co-Enzyme Q10) & $2 \mathrm{oz}$ & $\$ 34.00$ \\
\hline \multicolumn{4}{|c|}{ Starter Skin Care Programs - travel size kits $(1 \mathrm{oz} \& .5 \mathrm{oz})$} \\
\hline & Healthy Skin Maintenance (Normal to Oily) & & $\$ 56.00$ \\
\hline & The Luxe Kit (Normal to Dry) & & $\$ 65.00$ \\
\hline & Clear-Up Now! Starter Kit (Acne / Blemish Control) & & $\$ 65.00$ \\
\hline & Post IPL Laser Treatment / Skin Soothing Kit (Sensitive Skin) & & $\$ 58.00$ \\
\hline
\end{tabular}




\begin{tabular}{|c|c|c|c|}
\hline Qty & Item Description & Size & Retail \\
\hline \multicolumn{4}{|c|}{ Specialty Care } \\
\hline & Amino Pro Mist & $8 \mathrm{oz}$ & $\$ 32.00$ \\
\hline & Aloe Rose Mist & $8 \mathrm{oz}$ & $\$ 34.00$ \\
\hline & Clear-Up Now! Toner & $8 \mathrm{oz}$ & $\$ 34.00$ \\
\hline & Beta G Lotion - Anti-Inflammatory & $2 \mathrm{oz}$ & $\$ 38.00$ \\
\hline & Beta Hydroxy Lotion - Reduce Pores \& Smooth & $2 \mathrm{oz}$ & $\$ 38.00$ \\
\hline & Stop-The-Clock! Crème - With UGL Complex & $2 \mathrm{oz}$ & $\$ 48.00$ \\
\hline & Daily Dose - with AlphaLipoic Acid \& DMAE & $2 \mathrm{oz}$ & $\$ 48.00$ \\
\hline & Vitamin C Therapy Serum - with Hyaluronic Acid & $1 \mathrm{oz}$ & $\$ 52.00$ \\
\hline & Vitaminic Complex Serum & $1 \mathrm{oz}$ & $\$ 42.00$ \\
\hline & Raspberry Booster - Micelized Vitamin E & $1 \mathrm{oz}$ & $\$ 42.00$ \\
\hline & Illumine PM - 10\% Glycolic Acid & $2 \mathrm{oz}$ & $\$ 44.00$ \\
\hline & AHA Lightening Crème - 2\% HydroQ + Glycolic Acid & $2 \mathrm{oz}$ & $\$ 44.00$ \\
\hline & Lighten Up! - Lighten \& brighten skin & $2 \mathrm{oz}$ & $\$ 42.00$ \\
\hline & Skin Soothing Lotion -Anti-inflammatory & $2 \mathrm{oz}$ & $\$ 38.00$ \\
\hline \multicolumn{4}{|c|}{ Make-Up } \\
\hline & ProDerma Camouflage- Honey & $2 \mathrm{oz}$ & $\$ 64.00$ \\
\hline & ProDerma Camouflage - Ivory & $2 \mathrm{oz}$ & $\$ 64.00$ \\
\hline & ProDerma Camouflage-Almond & $2 \mathrm{oz}$ & $\$ 64.00$ \\
\hline & ProDerma Camouflage - Beige & $2 \mathrm{oz}$ & $\$ 64.00$ \\
\hline & ProDerma Camouflage - Crème & $2 \mathrm{oz}$ & $\$ 64.00$ \\
\hline \multicolumn{4}{|c|}{ Sun Protection } \\
\hline & Moisture Screen, SPF 30 & $4 \mathrm{oz}$ & $\$ 38.00$ \\
\hline \multicolumn{4}{|c|}{ Eye Care } \\
\hline & Eye Luxe - With CoQ10 & $15 \mathrm{ml}$ & $\$ 44.00$ \\
\hline & NutriCare Eye Creme & $15 \mathrm{ml}$ & $\$ 42.00$ \\
\hline & Eyes Wide Open - Firming Gel w/ Peptides & $15 \mathrm{ml}$ & $\$ 42.00$ \\
\hline \multicolumn{4}{|c|}{ Advanced Pore Treatment } \\
\hline & Pore Treatment & $2 \mathrm{oz}$ & $\$ 42.00$ \\
\hline & Clear-Up Now! Lotion - with $3.5 \%$ Benzoyl Peroxide & $4 \mathrm{oz}$ & $\$ 38.00$ \\
\hline & Clear-Up- Now! Trio - CUN Cleanser, Toner, Lotion & & $\$ 98.00$ \\
\hline & Clear Up Solution: $10 \% \mathrm{BPO} / 20 \%$ Sulfur & $4 \mathrm{oz}$ & $\$ 58.00$ \\
\hline & Clear-up Solution: $10 \%$ BPO, $10 \%$ Sulfur & $1.8 \mathrm{oz}$ & $\$ 32.00$ \\
\hline \multicolumn{4}{|c|}{ Body Care } \\
\hline & Hand/Body Treatment Crème & $2 \mathrm{oz}$ & $\$ 26.00$ \\
\hline & Body Perfect - with Shea Butter & $4 \mathrm{oz}$ & $\$ 18.00$ \\
\hline
\end{tabular}

\section{THE NEXT STEP: DISTRIBUTOR RECRUITMENT}

Jim and Mina Glassman have both had successful careers prior to creating Healthy Skin Naturally; Ms. Glassman as a Family Therapist, and Mr. Glassman as an entrepreneur, owning over thirty radio stations and ten newspapers in his media career. They view Healthy Skin Naturally as giving them the opportunity to work and spend more time together developing and growing the business.

Since the sales goal of $\$ 500,000$ a year represents an increase of more than ten times their current annual sales, in a relatively short period of time, the Glassmans have to begin marketing in a more aggressive fashion that they are now. Attaining their goal of $\$ 500,000$, affords them a good amount of gross profit. It's important to understand the Glassmans' game plan of why they believe they can grow so rapidly.

Based on an average gross profit margin of 50\%, sales to spas, physicians, and others, the Glassmans will attain a gross profit of $\$ 250,000$ upon having wholesale sales of $\$ 500,000$. As well, they are asking their retailers to keystone the cost when selling to customers. For example, on a product where the Glassman have production costs of $\$ 5$, they would wholesale the product to the distributor for $\$ 10$. The retailer would then turn around and double the wholesale cost to retail the product at $\$ 20$. 
Increasing sales more than tenfold will be a formidable task. The Glassmans, however, have a plan as to how they can get to the $\$ 500,000$ sales goal. The plan starts by adding new distributors. At the moment, their sole distributor, a physician, purchases $\$ 13,000$ worth of Healthy Skin Naturally products annually. Jim Glassman is targeting the company to add one more similar sized distributor before the end of the current year.

Next year, the goal of the company is to add one new distributor each month. By the end of next year, that would give them fourteen distributors. Annualized billing at $\$ 13,000$ per year per account (a projected average; the amount of the current distributor) totals $\$ 182,000$ in gross sales. The end of the second year goal is to add two new distributors each month. By the end of that year, the company would have thirty-eight distributors.

That sets the stage for the third year. Assuming the company does not add or lose anymore distributors, the annualized sales of thirty-eight distributors at $\$ 13,000$ per year totals $\$ 494,000$ in sales. Adding in the amount of sales done directly by the Glassmans to long time personal clients (which are paying the retail price), the total sales will exceed $\$ 500,000$.

Thus, after covering production costs, approximately $50 \%$ of the wholesale cost, the Glassmans will earn a gross profit of over $\$ 250,000$ in that year.

\begin{tabular}{|l|c|c|c|}
\hline \multicolumn{4}{|c|}{ Distributor Goal And Corresponding Annualized Sales And Gross Profit } \\
\hline & End Current Year & End of year one & End of year two \\
\hline Number Of Distributors & 2 & 14 & 38 \\
\hline Annual Sales Average & $\$ 13,000.00$ & $\$ 13,000.00$ & $\$ 13,000.00$ \\
\hline & & & $\$ 182,000.00$ \\
\hline Total Gross Sales & $\$ 26,000.00$ & $\$ 91,000.00$ & $\$ 247,000.00$ \\
\hline Production Costs & $\$ 13,000.00$ & $\$ \mathbf{9 1 , 0 0 0 . 0 0}$ & $\$ \mathbf{2 4 7 , 0 0 0 . 0 0}$ \\
\hline Gross Profit & $\$ \mathbf{1 3 , 0 0 0 . 0 0}$ & &
\end{tabular}

\section{PROFITABILITY PER DISTRIBUTOR}

The Glassmans have evaluated all the different channels of distribution, and have decided, initially anyway, that the best way to distribute their product is through the channel of distribution of selling the Healthy Skin Naturally line in spas and through dermatologists and plastic surgeons. The products will be sold by skincare therapists and estheticians working in the spas as well as being recommended by the physicians who will have two different options in which to sell the line.

Working as a Skincare Therapist and as an Esthetician in southern California spas herself, Ms. Glassman understands the ideal profitable marketing practices of spa owners. She understands that the key to selling product in the spas is helping the Estheticians accomplish their goal of satisfying individual clients. So, primarily, the Glassmans will target spas and physicians in the aforementioned geography between Santa Barbara and San Diego for distribution of Healthy Skin Naturally products.

In medical practices, the dermatologists and plastic surgeons will have two options in marketing the Healthy Skin Naturally line. They can provide the product and allow the physician's office to put their own private label on it, or they can put the product in the physician's office to sell with their Healthy Skin Naturally label. The Glassmans do consider the physicians market and the spa industry to have similar sales potential per location.

To see why the Glassmans have chosen this distribution strategy, an understanding of the mathematics of the sales process at a spa is important. An average spa, according to the Glassmans, may do twenty facials a day, Monday thru Saturday. That totals 120 facials each week, at an average price of $\$ 100$. That's gross sales each week of $\$ 12,000$ or a yearly total at fifty weeks per year of $\$ 600,000$. An Esthetician working in a spa is generally expected to sell each facial customer follow-up products after the facial, with an average sale of $\$ 25$ to each person. This is a generally accepted practice in a spa; additional sales of products are required of Estheticians, according to Mr. Glassman. 
At $\$ 25$ in additional sales to each person getting a facial, the spa grosses $\$ 3000$ a week or $\$ 150,000$ per year in additional sales based on 120 facials per week based on fifty weeks out of the year. Generally, a spa will carry no more than three or four lines of skincare products. If Healthy Skin Naturally only attains $20 \%$ of the spas $\$ 150,000$ in additional sales, that represents $\$ 30,000$ in retail sales of Healthy Skin Naturally products. At a fifty per cent profit margin, that represents $\$ 15,000$ in sales to Healthy Skin Naturally.

The $\$ 15,000$ in sales is just a bit over the $\$ 13,000$ per sales per year the Glassmans are projecting as their average per distributor (as explained earlier).

\section{HEALTHY SKIN NATURALLY'S COMPETITIVE ADVANTAGE}

To earn the $20 \%$ they feel they have an opportunity to earn, the Glassmans intend to use their knowledge of the industry as their competitive advantage, by providing training to the Estheticians in the use of the products. At the moment, very little if any training is done by the companies providing skin care products, as they consider the market too vast, too difficult, and too expensive to cover properly.

The Glassmans are taking advantage of the fact that they can bring the President of the company, Ms. Glassman herself, into the spas to do the training. In addition, the company also has another skincare therapist on staff, Kristen Scott, who is also available to do the training. As a student of Ms. Glassman, she understands the products, how they work, how they need to be applied, and how to work with Estheticians.

It's been learned from meetings with spa owners that the time spent training by a consultant from Healthy Skin Naturally will be welcomed and encouraged by the owners and the employees, as they realize the benefit of increased sales, and better educated Estheticians.

In addition, spas, like every business, have a certain amount of turnover. The Glassmans believe that it will be necessary to do three hours of training twice a year with each distributor, so the new employees of the business will not go too long of a period of time without learning about the Healthy Skin Naturally products.

The three hour session will be spent instructing the new Estheticians and reviewing with the more experienced Estheticians the benefits of the products and how to present them to customers. In addition, the Glassmans intend to incentivize the Estheticians by offering gifts such as gift cards or debit cards to be awarded by the spa owner after certain levels of sales are accomplished by the employees.

It's often been observed that the size of prize is not as important as the recognition associated with it and what the prize symbolizes. Often, a $\$ 20$ mall gift certificate may be perceived to be just as highly valued as a $\$ 50$ bill. After all, "it's for a shopping trip!" This is a lesson Mr. Glassman learned from awarding prizes to winner in the broadcasting business.

However, the Glassmans realize that the Estheticians will not recommend the product, no matter what the incentives are, unless they are believers in the products themselves. Therefore, the three hours of training two times a year is critical to the success of Healthy Skin Naturally. In short, these training hours need to be invested in showing the Estheticians that the products are effective and how to present them to their clients.

The Glassmans are considering other ways to incentivize the Estheticians. One thought would be to treat them to a day at Disneyland in southern California or some other sort of trip or meeting that would bring the Estheticians together.

By attacking the market aggressively through the aspects of service and training, the Glassmans believe they can succeed. In 2014, with 38 distributors each requiring a minimum of six hours per year in training, this commitment to their distributors will require the Glassmans to carefully plan the duties of Ms. Glassman and Ms. Scott. The 228 hours of training represents nearly six weeks of work of one employee on a forty hour a week work schedule. 
Assuming that each training period will take an additional three hours in preparation and travel, the number of hours committed to training and service total 456 hours in a year. The training and incentivizing are no small tasks. If these responsibilities remain with Ms. Glassman and Ms. Scott, there are other aspects of the business that will fall to Mr. Glassman and other employees he may need to hire.

A secondary form of distribution of Healthy Skin Naturally will be over the internet. The products will be available at the site, but only when the prospective buyer first enters her own zip code. If the zip code is one where there is already a distributor, the website will direct the buyer to that distributor. If there is not a distributor in the buyer's zip code, the purchaser will be able to buy from the internet site.

\section{COMPETITION AND PRICING}

When asked about competition, the Glassmans point out that they do not feel that they want to compete against the "over-the-counter" skincare products. To begin with, they do not have the financial wherewithal to compete against big companies such as Clinique and Dermalogica.

In addition, another international competitor that is primarily marketed on television is the acne cure Proactive. The full name of the product is Proactiv Solution, with the main ingredient being benzoyl peroxide. It has been endorsed by celebrities and sold through direct marketing infomercials. (The Federal Trade Commission requires celebrity endorsers to actually use the product.) The Glassmans do not feel Proactiv to be a company to compete against either, due to the fact that the product has probably already been tried as a solution to acne before an acne sufferer will try one of the Healthy Skin Naturally products. The product is very well known due to the huge amount of advertising and publicity it receives.

As stated earlier, the Glassmans believe distribution through spas and physicians is the ideal way to distribute the Healthy Skin Naturally products. They point out that by the time a potential customer goes to an Esthetician at the spa or they get to see a dermatologist, they have already exhausted the possible solutions that are sold over-the-counter or via direct marketing, such as Proactiv mentioned before, and found them to be lacking.

Without the funds to have much of an impact via television advertising or infomercials, nor the funds to set up nationwide distribution in drug store chains such as Walgreens or department stores such as Macy's, the Glassmans see the spa and physician alternative as the least expensive way (as well as the most effective) to grow the business.

Pricing, however, does not appear to be an issue for Healthy Skin Naturally. The retail pricing for the Healthy Skin Naturally products, upon comparison to other skin care products, is in the mid- to-upper range, according to the Glassmans. If the products were placed in a department store or a drug store, the products would "have a few higher priced competitors, but more lower priced competitors," said Mr. Glassman.

"The real test of any skincare treatment is the satisfaction with the product," according to Ms. Glassman. "If it works, and it's the only product that works for you, the price really doesn't matter. If it doesn't work, then the price of that skincare product would be perceived to be pretty high-basically, a waste of money."

Despite having the belief that pricing is secondary to satisfaction, the Glassmans are planning to continue to price their product in the mid-range in order to not lose out on any sales because the products are priced too high. "We sincerely want to keep Healthy Skin Naturally products affordable for most people," says Ms. Glassman.

Presently, on the Healthy Skin Naturally website (www.healthyskinnaturally.com), the Glassmans have sorted products into groups depending upon the needs of the buyer. They include:

- $\quad$ Normal to Oily (six products) retailing in a kit for $\$ 169.00$

- $\quad$ Stop the Clock! (eight products) retailing a kit for $\$ 387.00$ (not discounted)

- $\quad$ Body Care (two products) retailing together for $\$ 70.00$ (not discounted)

- $\quad$ Sensitive Skin (eight products) retailing together for $\$ 140.00$ 
- $\quad$ Normal to Dry (nine products) retailing together for $\$ 207.00$

- Clear Up Now! (seven products) retailing together for \$135.00 (mild acne); \$150 (moderate to acute acne)

Ms. Glassman says that while selling these products together makes the most sense, she admits that few of her patients have bought entire kits for their problems. This is a concept that saves the customer approximately 25\% rather than if each product was purchased individually. She is in a quandary as to how to make selling "in a kit" more attractive to her customers.

There are products specifically for men as well as for women; however, there are no products that are specifically created only for men.

The best selling products of the Healthy Skin Naturally line include:

- $\quad$ Vitamin C therapy

- $\quad$ Stop the Clock crème.

- $\quad$ Oak Cleanser

- $\quad$ Clear Up Scrub, Toner, Cleanser, Mask

- $\quad$ Moisturizer Screen spf 30

- Beta hydroxy acid solution

Nearly all of the products are formulated and packaged by the company. Some are purchased from other suppliers, however, and are repackaged under the Health Skin Naturally brand.

\section{PROMOTIONAL STRATEGY}

Of concern to the Glassmans is how to promote Healthy Skin Naturally. Mr. Glassman has a background in marketing and media, being involved in media ownership since 1972. At present, Mr. Glassman also works as a consultant to businesses and non-profit organizations on their marketing and advertising needs.

As the amount of capital to finance a nationwide or even simply a southern California wide advertising and marketing campaign is almost cost prohibitive, according to the Glassmans, it appears that the company has decided on more of a 'PUSH' strategy in promoting the Healthy Skin Naturally products.

By calling on spas and physicians on a one-on-one basis, incentivizing the employees to recommend the Healthy Skin Naturally line, the company hopes that this will 'push' the spas to becoming big supporters of the products and recommend them with no hesitation. The calls to the spa owners and physicians will be done by Mr. Glassman, with assistance on the face to face presentation from Ms. Glassman and Ms. Scott.

The Glassmans are hoping that simple 'word-of-mouth' advertising will help the company succeed. The more satisfied customers they create, the more the 'word' will spread about the effectiveness of Healthy Skin Naturally products.

Creating a viral buzz via Facebook and other social media is being considered as well. At this point, however, they are not certain what sort of campaign would create the 'buzz' they will need to properly launch the Healthy Skin Naturally line.

Other plans considered by the Glassmans include trying to secure a celebrity spokesperson for the products. Doing so in a market such as southern California could be very effective. Securing the spokesperson, however, will not be effective until she can do commercials or ads for the company. As we've discussed, funds are limited and initially there is no plan to invest in media advertising.

In that same fashion of spokespeople, they've started using testimonials provided by satisfied customers on the company's website. This can help with building credibility of the product. A question that the Glassmans need to answer, though, is how do you drive traffic to your website when you have a no budget to work with? 
The presentation of free clinics inside spas also holds possibilities for the company. Going to a spa on a Saturday morning or afternoon and having a company representative offering free samples will not only secure goodwill with the spa owners, but will get the word out faster about the efficacy of the Healthy Skin Naturally line. Giving out free samples to spa visitors would cost the Glassmans very little in terms of merchandise and personnel. If a different spa had a free clinic every week at a cost of $\$ 500$ per clinic, it would total approximately $\$ 26,000$ in yearly cost.

Once again, effectively spreading the word about Healthy Skin Naturally would indeed provide much needed assistance in the name recognition of the products, not only with potential customers, but also with Estheticians and owners of spas, as well as dermatologists and plastic surgeons.

\section{CONSIDERING E-COMMERCE SOLUTIONS}

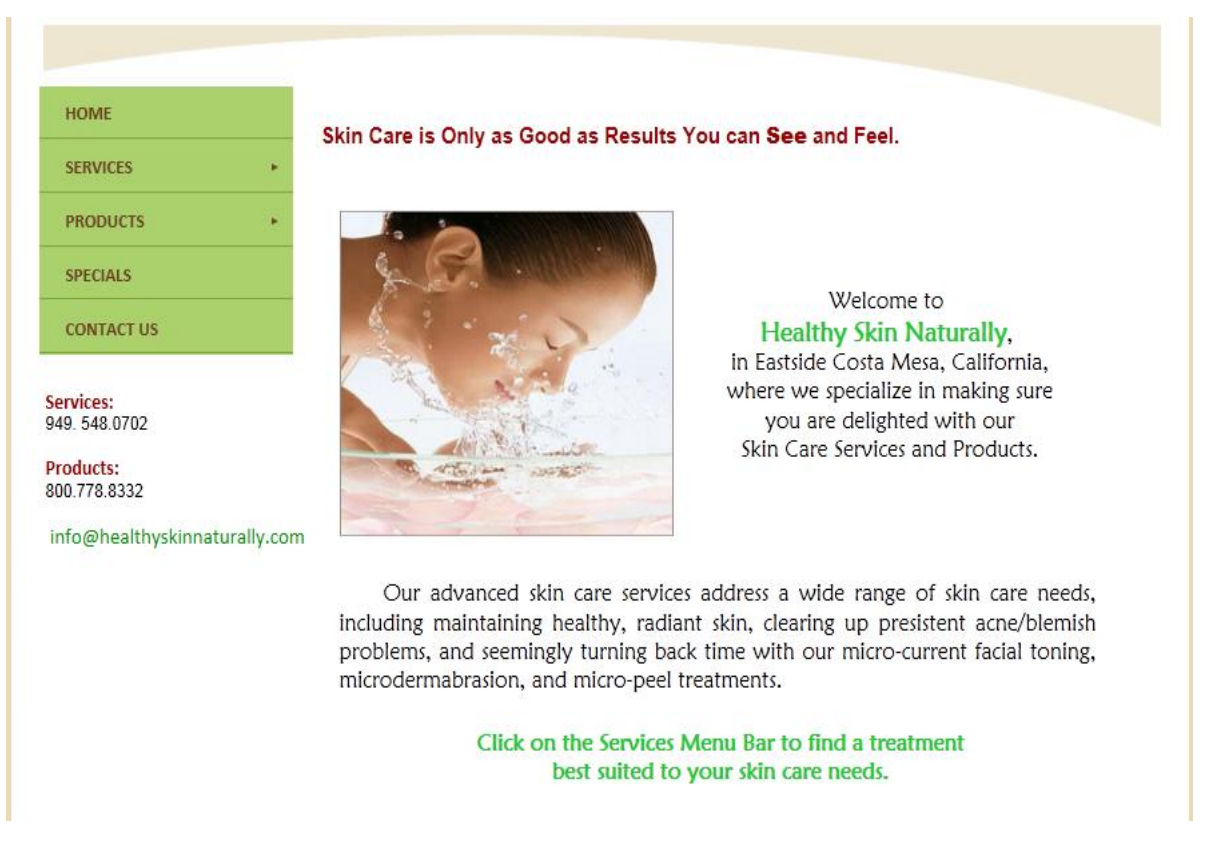

$\underline{\text { www.healthyskinnaturally.com }}$

The Glassmans are just beginning to consider Internet options for their sales. While they have a very attractive, somewhat informative web site, there is the problem of getting potential customers to actually view the site. The best web site possible cannot be a marketing tool if it isn't readily found. A Google search for "Healthy Skin" results a list of "About 29,800,000 results ( 0.17 seconds)." A link for HealthySkinNaturally.com does not appear within the first 8 pages of results for this search. The probability that a potential customer would search that deeply to find a solution to his or her skin problems is very close to zero. Searches for "Skin Problems", "Facial Skin Problems and Solutions" and similar terms yielded similar results. A search for "Healthy Skin Naturally" yields this web site as the second item; however, how likely is it that a customer would happen upon the exact brand name unless they were already aware of these products?

So the Glassmans are concerned about how they can get customers to find the Healthy Skin Naturally web site. Mina and Jim Glassman have seen Internet pop-up, video or banner ads for similar products. Most ads appear on individual company web sites, although these ads also appear on sites such as YouTube, Amazon, Facebook, Twitter and MySpace. Such ads also appear beside the results of a web search. The Glassmans wonder how much they can do to improve their web presence with their busy schedules and no budget for this type of advertising. 
In a recent staff meeting, Ms. Scott broached the possibility of the cost-effectiveness of subscribing to an Internet Search service, in order to help drive more traffic to their web site. She has found some relatively inexpensive business registration services which offer to bring up the business name, logo, phone number, description, etc. as a result of a web search. This type of registration also allows several links to the website which should drive traffic directly to the web site. She does wonder about the viability of such a service and she also wonders about how much traffic to the web site would increase through such a service. Ms. Scott and Ms Glassman do not wonder about whether their product would sell over the Internet. They feel that their products speak for themselves. They also feel that customer testimonials featured on their web site (such as: "The reason I started using these products is that my best friend looked so good. Need I say more? Marilyn S") could be improved upon.

Ms. Glassman and Ms. Scott have questioned the effectiveness of this type of testimonial. They have noticed that web video ads for this type of product are often in the form of some young woman with very nice skin talking to the audience about the causes of their skin conditions and the benefits of a specific product. They feel there is some way to improve on these infomercials, but have not yet decided on the type of video they would prefer to use. A customer who formerly suffered from an acute case of acne suggested that it would be useful for others to see someone like her gradually improving, with a voice over telling about the "Clear Up Now!" product line. While this is an interesting idea, neither feels that she has enough knowledge to produce such a video and they are reluctant to invest their promotional budget on hiring professional help for such an endeavor.

Mina had other concerns about pursing an e-commerce approach. For example, how would existing distributors view the website - as complementary, or as competition? Might the website make it more difficult to secure new distributors? Would the website be able to answer questions for the customer? Or would the website end up driving customers away from repeat usage of the product. These would seem to be significant issues, thought Mina, and need to be addressed before we move forward.

\section{DRIVING OFF INTO THE SUNSET}

It was now early evening, and Mina and Jim Glassman were walking back to their cars having had a successful sales call earlier in the afternoon with their spa prospect. The spa owner agreed to start carrying the Healthy Skin Naturally at the beginning of the next year. As Mina pulled her red Thunderbird convertible out of the parking lot, she reflected that if all goes well in the next three years, she could successfully make the transition into the Healthy Skin Naturally business on a fulltime basis. Based upon the day's success, she felt confident, but as all of us do when it comes to thinking about the future, she wondered what the next few years would hold in store for her and Jim and Healthy Skin Naturally. Meanwhile, on Mina's car radio, Journey's classic song "Don't Stop Believing" began to play. How appropriate! thought Mina.

\section{DISCUSSION QUESTIONS / ACTIVITIES}

1. Conduct a SWOT analysis for Healthy Skin Naturally. How might the Glassman's convert any weaknesses to strengths? Threats to opportunities? Can they match any specific strength's with opportunities?

2. Prepare a statement which describes the Healthy Skin Naturally branding proposition (it might be useful in answering this question to visit the brand's website at healthyskinnaturally.com). How does the positioning of the brand compare to the Glassman's definition of their target market? What additional research might be needed in order to further define the target market?

3. Is the $\$ 500,000$ sales goal a reasonable or achievable goal? What are the key success factors which are necessary in order to be successful in this product category (skin care products)? What possible competitive advantage(s) does Healthy Skin Naturally hold?

4. Compare and contrast the different possible distribution strategies for this product line; what are the potential advantages and disadvantages of each? Which of these strategies would be most likely to succeed and why?

5. Assume the Glassman's have $\$ 200,000$ to spend on a promotional campaign for Healthy Skin Naturally. Develop a detailed promotional strategy and supporting budget, and also calculate the break-even point in dollar sales required to cover the $\$ 200,000$ promotional budget. 
6. Develop (and deliver) a 10-minute presentation which would be given to prospective distributors (for example, spa owners). Have someone in the class role play as the spa owner, and other class members evaluate the quality of the sales presentation. How might the sales presentation be improved? How would the sales presentation be changed for a different type of distributor (a physician, for example)?

7. Many companies are now focusing on e-commerce as a way to directly communicate and exchange with customers. Discuss and evaluate any possible sources of channel conflict which might result from the Glassman's using an e-commerce strategy to distribute their products. How might this conflict be resolved?

\section{AUTHOR INFORMATION}

Henry B. Balfanz is in his first year of teaching fulltime after having a long career in the broadcast, newspaper, and advertising industries. He is a graduate of Southern Illinois University at Carbondale with his MBA completed at Bradley University in Peoria, IL. His media experience includes twenty plus years as a Vice President/General Manager of radio stations, a six year tenure as a newspaper Publisher, and a recent two year stint as Vice President of an ad agency in Peoria, IL. Balfanz joined the Northern Michigan University faculty in August 2011. E-mail: hbalfanz@nmu.edu

Gary J. Brunswick holds a Ph.D. in Business Administration from Arizona State University, and currently hold the rank of Professor of Marketing at Northern Michigan University. His research interests include marketing strategy, services marketing and e-commerce. His research has been published in range of journals including, Journal of the Academy of Marketing Science, Journal of Consumer Behaviour, The Marketing Management Journal, The Journal of Professional Services Marketing, The International Journal of Case Studies and Research. The Journal of the International Academy of Case Studies, The Academy of Educational Leadership Journal and The Academy of Marketing Studies Journal. E-mail: gbrunswi@ nmu.edu. Corresponding author.

Margaret M. Sklar has served in higher education since 1980. She received her Baccalaureate degree from Rosemont College (Mathematics); her MA from the University of Detroit (Computer Science) and her PH.D. from the University of Cincinnati (Information Systems). She taught as an adjunct at the University of Detroit for several years, as a member of the Mathematics and Computer Science departments at Marygrove College and joined the College of Business at Northern Michigan University in 1983, teaching Computer Information Systems. She has served as an administrator in the College since 2001 and is currently the Associate Dean. E-mail: msklar@nmu.edu 